DOI https://doi.org/10.18551/rjoas.2021-03.08

\title{
POLICY IMPLEMENTATION OF EMPOWERMENT PROGRAM FOR SMES AT BANDUNG DISTRICT OF WEST JAVA, INDONESIA
}

\author{
Jaenudin Jejen*, Candradewini, Halimah Mas \\ Faculty of Social and Political Sciences, University of Padjadjaran, Indonesia \\ ${ }^{*}$ E-mail: jaenudinjejen31@gmail.com
}

\begin{abstract}
This research was conducted based on a phenomenon regarding the empowerment program for Small and Medium Enterprises (SMEs) in the form of equity that occurred in Bandung Regency. The issue of empowering SMEs is a very interesting policy issue to discuss because in this issue many factors determine the success of policy implementation, to be used as material for evaluation and consideration by both the Bandung Regency government and other regions in implementing policies so that it can run well and achieving goals. The implementation of the capital participation policy in Bandung Regency is based on local government regulations, namely in Regional Regulation Number 7 of 2013 concerning Equity Participation in Non-Banking Microfinance Institutions (Cooperatives and Non-Cooperatives) through Banking. This study uses a descriptive method with a qualitative approach to find out the answer to the question of how to implement policies through Equity Participation and what are the factors that are supporting and hindering Capital Participation policies in Bandung Regency. The results of this study indicate that the Bandung Regency Government has implemented a policy of empowerment through equity by Regional Regulation Number 7 of 2013 concerning Equity Participation through the Empowerment Program for Cooperatives, SMEs in Bandung Regency, namely providing good services in borrowing. Main activities include Socialization of policies, requirements for applying for capital loans, Procedures for disbursing and repaying capital loans. The Service Technical Team, Verification Team, and Implementing Bank as policy executing actors have also carried out their duties and responsibilities properly.
\end{abstract}

\section{KEY WORDS}

Policy implementation, SMEs; equity capital, Bandung district.

The existence of small and medium enterprises (SMEs) reflects the real form of the social and economic life of the largest part of the Indonesian people. The large role of SMEs is shown by their contribution to national production, the number of business units and entrepreneurs, and the absorption of labor (Suharto, 2006). The survivability of SMEs in the structure of the economy during this crisis has contributed greatly to the revitalization and growth of Indonesia's economy at that time. Given that SMEs are an important part of the economy of a society and the state, the government has begun to focus on the existence of SMEs by issuing various policies that encourage the growth and development of SMEs (Kurniawan and Fauziah 2014; Wulansari, Wahyu, and Kurniawan 2017).

Regarding the role of the government in empowerment to handle public problems that occur, one of the phenomena currently developing is about SMEs. One of the provinces that have a significant role in the Indonesian economy is West Java. In 2018, the economy of West Java Province contributed around $13.39 \%$ to the total national economy and around $24.58 \%$. With this value, West Java is one of the largest provinces that contribute to the value of Indonesia's GDP. The West Java Central Statistics Agency recorded that the economic growth of West Java in 2018 grew 5.29\% (BPS Provinsi Jawa Barat, 2018).

Bandung Regency plays an important role in West Java Gross Regional Domestic Product. One of them is in the SME sector that has absorbed large jobs. Industry in Bandung Regency focuses on the process of changing basic goods mechanically, chemically, or by hand so that they become finished goods and goods of less value become goods of higher value, and are closer to the end-user, starting from relatively traditional industries to those 
using the latest technology. Based on data from BPS Bandung Regency, the number of SME units in Bandung Regency is 1054 units, absorbing a workforce of 169,486 people, and a production value of IDR 61,050,182,144.

Behind the strengths, they have, however, SMEs face weaknesses or internal obstacles, one of which is the problem of credit and capital in starting and developing their business. Credit and capital for SMEs are often the main obstacles because business actors have very limited ability to access credit or banking institutions (Kurniawan, 2014). So it is important for these small entrepreneurs in their ability to access sources of financial capital both from the formal sector and the informal sector (De Meza et al., 2008; Taylor, 2011). To increase production, SMEs certainly need a lot of capital. In this case, high competition and changes in the consumer behavior cannot be ignored. On the other hand, the managers' lack of knowledge and lack of capital have made the majority of micro, small and medium enterprises unable to survive for long. The problem of capital and access to financing sources is the most crucial (Rachbini, 2020).

SMEs are also still facing various problems related to the business climate such as 1) The number of transaction costs, the length of the licensing process, and the incidence of various levies; and 2) Unhealthy business practices. Also, regional autonomy, which is expected to be able to accelerate the growth of a conducive business climate for SMEs, has not shown equitable progress.

Various credit requirements faced by business actors such as preparing documents, photocopies of identity, collateral or guarantees, financial reports, business licensing documents, checking accounts, and making business proposals. This requirement is considered to be very troublesome and burdensome for business actors where many small business actors complain about their inability to meet the stipulated requirements. Apart from the business conditions that make it impossible to provide appropriate guarantees, the procedures also tend to be convoluted.

One simple example is that many business actors have to meet requirements in the form of financial reports and business development proposals, which for them feels difficult to do because they cannot record which is adjusted by the credit party. Banking institutions also charge high-interest rates to their creditors, most of the creditors of banking institutions are large entrepreneurs. Even though many credit services provide loans to SMEs with easy requirements and a fast loan process, the high-interest returns and short repayment periods are very burdensome for Business Actors.

The above situation is directly related to 1) The low quality of human resources, especially in management, organization, technology, and marketing; 2) Weak average entrepreneurial competence; and 3) Limited capacity of SMEs to access capital, information technology, and markets, as well as other production factors. The progress of SMEs is very supportive of efforts to overcome inequality among actors, between income groups, and between regions, including poverty alleviation.

Although there are efforts to restore the SME sector from the government, the results have not been as expected. The central and local governments must conduct rescheduling, injection of loans, defer the execution of guarantees for SMEs. However, they have not been able to stop the decline in the performance of SMEs and there have been many complaints from SMEs about the threat of debt collectors and the confiscation of assets of SMEs. The credit restructuring policy is insufficient if it is not accompanied by technical assistance to accelerate recovery, such as mentoring and training. Currently, what businesses with nonperforming loans most need is capital so that they can get up quickly.

The Government of Bandung Regency in observing the development of major changes in the implementation of empowerment of SMEs at the national level, provincial level, which directly affects the implementation of empowerment programs for SMEs at the regional level by formulating several important problems that will become objects in the draft Regional Regulation. The existing revolving fund loan assistance programs, both programs rolled out by the Central, Provincial and Bandung Regency Governments, while the above programs have not been able to touch all levels of society, especially SMEs actors, so an 
empowerment program is needed which is handled and funded by the District Government through the Regency Regional Revenue and Expenditure Budget.

The Regional Government of Bandung Regency seeks to assist SME actors in developing businesses through support, one of which is in the form of regulations. The policy in question is Regional Regulation Number 7 of 2013 concerning Equity in Non-Banking Microfinance Institutions (Cooperatives and Non-Cooperatives) through Banking in Bandung Regency.

In this regard, in evaluating the development of micro and small credit disbursement through Rural Banks in Bandung Regency in this study, referring to research conducted by (Uchida \& Udell, 2012) regarding lending to SMEs conducted in Japan which considers several rationales, namely; 1) The results of the study in Japan have the same variable measurement dimensions as the results of studies in Indonesia to measure relationship lending, namely a stronger relationship between banks and their debtors, which is a comparative advantage of small banks and cooperatives compared to large banks in extending micro and small loans. Meanwhile, large-scale banks prefer a transaction-based lending approach, namely credit approval based on analysis and assessment of debtor's financial statements; 2) In the Japanese financial market there is a phenomenon that many large banks have shifted from providing corporate loans to entering into the micro and small credit market segmentation, which is also the case in Indonesia; and 3) The results of the analysis of the study conducted in Japan also wanted to see how the prospective small banks in the future could still survive with the scale of the SMEs credit financing business in the banking industry, this is also the same as the purpose of writing, namely to see how the prospects for financing the micro and small sectors. in the future by banking (Uchida, Udell, \& Yamori, 2008; Uchida, Udell, \& Watanabe, 2008; Uchida et al., 2012).

Based on the explanation above, it can be concluded that with the increasingly dynamic development of regional, national, and international economies as well as the tighter business competition faced by SMEs players in the free market, to be able to act as a strong and independent business entity, capital and strong support from the central government and local governments. So that the purpose of this research is to know and analyze the implementation of the policy of Regional Regulation Number 7 of 2013 concerning Equity in Non-Banking Microfinance Institutions (Cooperatives and Non-Cooperatives) through Banking in Bandung Regency.

\section{LITERATURE REVIEW}

The economic vulnerability shown by this study requires the role of the public sector to overcome economic difficulties (economic hardship) (Cucculelli \& Ermini, 2012;2014; 2016;2017;2018; Xie et al., 2013; Omri et al., 2015). Financial capability has major implications for the welfare and ability of entrepreneurial activities (S. M. Taylor \& Wagland, 2013). In the scope of entrepreneurship, having high financial capabilities allows individuals to make better financial decisions, such as budgets, expenses, savings, investments, and financial risk management. However, the reality of the level of financial capability of business actors is still low (Hean et al., 2013).

In the context of small and medium-sized companies, according to (Noctor, M., Stoney, S., \& Stradling, 1995) financial capability is related to making the right financial decisions at the level of corporate strategic management, understanding how to manage credit and debt, and identifying business capital financing products and services that are corresponding. For society, financial capability is a necessity because it must be able to make informed judgments and make effective decisions about the use and management of money or funds (Fonseka et al., 2014; Johnson \& Sherraden, 2007). According to (Atkinson et al., 2007) a concept that emphasizes financial action and behavior for an entrepreneur. Meanwhile, financial literacy has a more general meaning, namely a knowledge or ability to manage individual finances such as in managing household finances and personal finances (Huston, 2010; Lusardi et al., 2010). 
Public policy according to (Pal, 2005) categorizes the definition of public policy into two types, namely definitions that emphasize the main aims and objectives of policies and definitions that emphasize the impact of government actions. Definitions that put more emphasis on the main aims and objectives of the policy can be identified, including (Doern \& Pal, 1988; Pal \& Ireland, 2009). (T. R. Dye, 2017) said that public policy is whatever the government chooses to do or not to do. This means that (1) public policies are made by the government, not private organizations, and (2) public policies regarding choices that should be made or not made by government agencies (Wright \& Jenkins, 1979; Nagel \& Kaplan, 1965).

In understanding the concept of public policy, there are at least four views on the meaning of the public policy. First is understanding public policy as decision-making. Second, a policy is interpreted as a series of work phases for public officials. Third, public policy is also a socio-cultural intervention by utilizing various instruments to solve public problems. Fourth, the deepest meaning of public policy is understanding public policy as an interaction between the state and its people to overcome public problems (Solichin, 2017).

According to (Budi, 2014) the term policy is used in daily practice but is used to replace a very different activity or decision. This term is often interchanged with goals, programs, decisions, standards, proposals, and grand designs. The public policy looks abstract and is even seen as something that happens to someone. The term policy is used to designate the behavior of an actor or several actors in a particular field of activity. This definition of policy can be used and is relatively adequate for ordinary discussions, but becomes inadequate for scientific and systematic discussions involving public policy analysis so that a more precise definition or concept of public policy is needed.

Three main points need to be considered in public policy analysis. First, the main focus is on clarifying policies, not on appropriate policy advice. Second, the causes and consequences of public policy are carefully investigated using the scientific method. Third, analysis is carried out to develop reliable general theories about public policies and their formation so that they can be applied to different institutions and policy fields (Winarno, 2012). At the stage of policy formulation and legitimacy (Meier et al., 1987) say that policy analysis needs to collect and analyze information related to the problem in question, then try to develop policy alternatives, build support and conduct negotiations, to arrive at a policy that is selected.

Public policies can be used for the discussion of various problems related to the social and economic conditions of society. Some examples of aspects that can be discussed are poverty level, unemployment rate, population, environmental problems, and others that can affect economic stability in a country. Each aspect is an aspect that is related to one another so that imbalances that occur in one or two aspects can affect the conditions of other aspects. (T. Dye, 2014) describes the relationship between public policy, the causes, and consequences that can arise. The causes in question are about various things that are the root of the problem that will be discussed to establish and implement a public policy. The consequences are related to the consequences arising from the implementation of the policy. Public policy that is implemented can be known what the effect of the feedback given to the institutions, processes, and behavior of the political system and government (T. R. Dye, 2017).

The most popular policy stages are public policy stages according to (Dunn, 2003) Agenda Development; Policy Formulation; Policy Adoption or Legitimacy; Policy Implementation; Policy Evaluation (Dunn \& Dunn, 2018). There are many implementation models according to experts, including public policy implementation models according to (Van Meter \& Van Horn, 1975) (Edward III, 1984) (Grindle, 2017). As for the meaning of implementation according to (Sabatier \& Mazmanian, 1980), saying that implementation is understanding what happens after a program is declared valid or formulated is the focus of attention to policy implementation, namely events and activities that arise after the legalization of State policy guidelines, which includes both efforts to administer it and to have a real impact/impact on society or events. 


\section{METHODS OF RESEARCH}

The research method is a systematic method and procedure which includes the collection and analysis of data (information) to find answers to existing problem phenomena. Selection of research methods as a basic guideline for researchers in planning the steps in a study systematically to achieve research objectives.

This type of research the writer uses is based on a qualitative approach with a descriptive nature. According to (Creswell, 2013) qualitative research methods can be interpreted as a research method based on post-positivism or interpretive philosophy, used to examine the conditions of natural objects (as opposed to experiments) where researchers are key instruments, data collection techniques are triangulated (combined), data analysis is qualitative inductive, and the results of qualitative research emphasize meaning rather than generalization. (Denzin \& Lincoln, 2000) states that qualitative research is research that uses a natural setting that intends to interpret the phenomena that occur and is carried out by involving various existing methods. Furthermore, descriptive research aims to accurately describe the characteristics of an individual, condition, symptom, particular group, or to determine the frequency or spread of a symptom or the frequency of a certain relationship between a symptom and other symptoms in society (Miles et al., 2014).

The object of this research is the implementation of capital participation settlement policy to non-banking microfinance institutions (non-cooperative cooperatives) through PT. Bank Perkreditan Rakyat Kerta Raharja, Bandung Regency, and the number of 6 (six) informants.

\section{RESULTS AND DISCUSSION}

Analysis of the Implementation of Equity Participation Policy. The Regional Government of Bandung Regency seeks to assist SME actors in developing businesses through support, one of which is in the form of regulations. The policy in question is Bandung Regency Regional Regulation Number 7 of 2013 concerning Equity Participation in NonBanking Microfinance Institutions (Cooperatives and Non-Cooperatives) through Banking in Bandung Regency.

In the implementation of the policy of Equity Participation through the Empowerment Program for SMEs, Bandung Regency is a revolving fund program carried out by the Bandung Regency government. Revolving funds are often interpreted as support funds whose utilization process is limited based on usage and time with a rolling usage pattern (consecutive diversion) from the first beneficiary to the next beneficiary. In this research, what is meant by the revolving fund program is the capital strengthening support provided by the Bandung Regency government to SMEs, which is channeled through PT. Bank Perkreditan Rakyat Kerta Raharja to be utilized through a revolving pattern, namely the funds that have been utilized by SMEs actors will be channeled back to other business actors in Bandung Regency.

The implementation of the Capital Participation policy through the Empowerment Program for SMEs of Bandung Regency is the implementation by the actors of the Bandung Regency government of the policies that have been made by the Bandung Regency Government, in this case, the Regent of Bandung Regency which then within a certain period can be evaluated whether the objectives the policy is achieved and is feasible or is it not feasible so that changes are needed.

Based on the results of the author's research, it shows that capital participation which is a loan from local revenue is very useful for SMEs entrepreneurs in Bandung Regency who obtain loans. In implementing the capital inclusion policy, the role of SMEs can contribute to Regional Original Income from each capital lent through the interest given.

This revolving fund program is not only able to make the number of SMEs growing steadily but a growing number of businesses because revolving funds come from principal installments paid by business actors as program participants from revolving fund loans 
received, to be rolled out to its members, as well as to other Business actors who have met the requirements by the applicable provisions.

Socialization of Capital Participation Policy Implementation. The Bandung Regency Government has carried out the socialization of capital participation policy for SMEs of Bandung Regency through several and electronic media in a good, efficient and effective manner so that many SMEs actor know about the capital participation program. Socialization will be more effective, efficient, and economical if the socialization is carried out directly by the government to all SMEs throughout Bandung Regency by meeting directly at the business location so that it is more targeted, easier, and clearer in conveying information, even business actors will feel happy because they feel cared for by the Bandung Regency Government, and the government can find out firsthand the conditions and problems faced by business actors in the field. Also, the operational costs are lower than the costs of socialization through electronic media and print media.

Requirements for SMEs. Some several steps and requirements must be taken and fulfilled by prospective participants of the SME program in obtaining a capital loan from the Bandung Regency government, these requirements are administrative. One of the advantages of this capital investment policy for SMEs is that the requirements needed to obtain capital for SMEs are easier and the process is faster and the interest is very low when compared to borrowing from other financial institutions.

During the application for a business capital loan to the Bandung Regency government, borrowers feel that the administrative requirements provided are quite easy to fulfill and the process is fast. Even though the interest rate returns are low and the process is fast, some business actors still find it difficult to fulfill several business requirements such as security, having to be registered in a business group, identity cards that have expired, and making business proposals. SMEs actors also encounter difficulties such as not having business legality in the form of a Trading Business License or Company Registration Certificate.

The problem of administrative requirements can be resolved by the business actor himself because these requirements are already lighter than borrowing from the banking sector, but it is hoped that the district government will further ease administrative requirements. There are business actors who say that they need unsecured capital loans, although it is very difficult to cancel the guarantee, the government must make efforts to facilitate services.

Procedures for Disbursement and Payment of Fund Loan Obligations. Disbursement of revolving capital strengthening loan funds for SMEs of Bandung Regency to Program participants (recipients of revolving pattern loan funds), is carried out by the Implementing Bank with predetermined procedures and requirements. This cooperation agreement is quite good because with the agreement there is a responsibility for each one that is formalized so that it has strong binding power.

Program participants are required to open a savings account for holding revolving funds at an executing bank whose administrative-technical provisions are regulated by the Implementing Bank, however, PT. Bank Perkreditan Rakyat Kerta Raharja should have a special program to accommodate capital loan funds from the government because if you open an account, business actors are not much different from borrowing at commercial banks even though this has something to do with borrowing capital from the government, besides that this program must be different from business actors borrowing from the regional PT. Bank Perkreditan Rakyat Kerta Raharja. The program must also make it easier for business actors not to complicate and prolong the process of disbursing capital loan funds by providing easy and fast requirements. Program Participants receive a revolving loan fund disbursement from the Implementing Bank by submitting the required documents.

Payment of program participant obligations to the Implementing Bank, in this case, is PT. Bank Perkreditan Rakyat Kerta Raharja, Bandung Regency has been regulated and established. The implementation went well. However, it is better if the handling of returns is the Technical Team for the Bandung Regency Government Service because of the costs incurred to work with PT. Bank Perkreditan Rakyat Kerta Raharja is not the least, besides that business actors are charged an interest of $7 \%$ of the total funds for these banking 
services, if this can be eliminated, the interest expense on capital loans for business actors will be lower. In cooperation with PT. Bank Perkreditan Rakyat Kerta Raharja is also prone to problems or conflicts. The authority of the Bandung Regency government will also decrease in terms of financial management because the income and expenditure are under the control of PT. Bank Perkreditan Rakyat Kerta Raharja, however, this must be supported by adequate human resources.

New Returns, Transfers, and Disbursements of Revolving Funds. New revolving fund distribution is the handing over of capital loan funds previously used by business actors after the loan period runs out, the funds are rolled back to other business actors and implemented in several stages. The new revolving loan funds that are collected and come from installments of each program participant are distributed to other prospective program participants (who meet the requirements) based on the proposal from the Technical Service Team which has been approved by the Verification Team and is then determined as a new program participant. New program participants (new revolving fund recipients) are required to meet the requirements according to the provisions. The purpose of control during the activity is as a preventive measure and control during the activation process so that activities are by what has been planned and determined. Activities that are evaluated by the Bandung Regency government include socialization of policies, coordination among implementing actors, verification of requirements files, monitoring of activities, and inspection periodically carried out by the Office Technical Team and the Verification Team.

In its implementation, there are still several shortcomings such as the absence of a more comprehensive business development counseling guidance and motivating business actors to increase their business. The lack of a loan repayment period is also a factor that is considered a lack of service to business actors, the loan repayment period should be more than 2 years so that it is easier for business actors to return it and take advantage of it. The lack of funding allocation is also a barrier faced during the implementation of the capital inclusion policy. Also, the Bandung Regency government has provided direction in doing business, but it needs seriousness and expertise in providing input and motivating business actors in facing an unstable economy.

Analysis of Policy Implementation Achievement. In public policy, several stages must be passed in resolving problems faced by the government as stated by public policy expert (Dunn, 2003) which consists of Agenda setting, policy formulation, Policy Legitimation, Implementation, Impact, and Termination. Policy implementation is a stage that is not easy, because there may be problems faced in the field that are not by the policy formulation, therefore policy implementation is a very important part of the policy process, this applies to the policy of capital participation for SMEs. and Menengah Kabupaten Bandung where problems are still encountered during implementation which differs from policy formulations such as lack of equity participation funds. As said (Bardach, 2009) stated that it is quite difficult to make a policy that looks good on paper, but even more difficult to formulate it into words that sound pleasant to the ears of leaders and voters who hear them, even more, difficult to implement them in a form and in a way that satisfies everyone including those who are considered clients (Bardach, 2017).

The concept of implementing the Equity Participation policy can be seen from the concepts of several policy implementation experts in Public Policy. In short, policy implementation is implementing, providing a means to carry out something. According to (Van Meter \& Van Horn, 1975) policy implementation is the actions taken by individuals or officials or government groups that are directed at achieving the goals outlined in policy decisions. So that the implementation of the Capital Participation policy through the Empowerment Program for SMEs of Bandung Regency is the actions taken by the Bandung Regency government, namely the Service Technical Team, the Verification Team, and the Implementing Bank which is directed at achieving the goals outlined in the policy decision namely increasing the ability of Bandung Regency SMEs in increasing their business so that they can survive and compete at local, national and international levels. 
Table 1 - Achievement Analysis of Policy Implementation

\begin{tabular}{|c|c|c|}
\hline Variable & Description & Implementation Achievement \\
\hline Policy rules & $\begin{array}{l}\text { Bandung Regency Regional Regulation } \\
\text { Number } 7 \text { of } 2013 \text { concerning Equity in } \\
\text { Non-Banking Microfinance Institutions } \\
\text { (Cooperatives and Non-Cooperatives) } \\
\text { through Banking }\end{array}$ & $\begin{array}{l}\text { There need to be improvements in some of the } \\
\text { substance of the policy so that there is a match } \\
\text { between the content of the policy and the field, } \\
\text { such as a lack of fund allocation and including } \\
\text { MSME actors in policy formulation }\end{array}$ \\
\hline Policy objectives & $\begin{array}{l}\text { Channeling of Rolling Pattern Capital } \\
\text { Strengthening Loans } \\
\text { The realization of an increase in capital } \\
\text { Realizing Regional Original Acceptance } \\
\text { as a form of direct participation from the } \\
\text { SME community } \\
\text { The realization of revolving loan funds } \\
\text { distributed to SMEs to other SMEs } \\
\text { Implementation of the Program and } \\
\text { Program Maintenance to strengthen } \\
\text { capital for SMEs }\end{array}$ & $\begin{array}{l}\text { The objectives of the capital participation policy } \\
\text { can be achieved well by the technical service } \\
\text { team, verification team, and implementing banks, } \\
\text { but it is necessary to continuously make } \\
\text { improvements and maintenance of program } \\
\text { implementation to strengthen capital for SMEs. }\end{array}$ \\
\hline $\begin{array}{l}\text { The characteristics of the } \\
\text { executing agency }\end{array}$ & $\begin{array}{l}\text { Duties and responsibilities of the official } \\
\text { technical team, the verification team, and } \\
\text { the executing bank }\end{array}$ & $\begin{array}{l}\text { The official technical team, verification team, and } \\
\text { implementing bank can understand and carry out } \\
\text { their respective duties and functions properly, } \\
\text { comply with rules, discipline, and be professional } \\
\text { in providing services to SME actors, but there is a } \\
\text { need for increased awareness, optimism, and } \\
\text { motivation to advance. SMEs Bandung Regency }\end{array}$ \\
\hline $\begin{array}{l}\text { Communication between } \\
\text { related organizations }\end{array}$ & $\begin{array}{l}\text { Coordination, meetings, and } \\
\text { communication between the official } \\
\text { technical team, the verification team, and } \\
\text { the implementing bank }\end{array}$ & $\begin{array}{l}\text { The official technical team, the verification team, } \\
\text { and the implementing bank held many meetings } \\
\text { during implementation as a form of coordination, } \\
\text { meetings, and communication, but there needs to } \\
\text { be an increase in the same goals and visions, } \\
\text { namely providing the best service to increase the } \\
\text { independence of SMEs in Bandung Regency, not } \\
\text { individualists. }\end{array}$ \\
\hline $\begin{array}{l}\text { The attitudes of the } \\
\text { implementers }\end{array}$ & $\begin{array}{l}\text { Discipline, professional, transparency, } \\
\text { bureaucracy, obeying rules, honesty, and } \\
\text { fairness in providing services to the } \\
\text { public }\end{array}$ & $\begin{array}{l}\text { The official technical team, the verification team, } \\
\text { and the implementing bank have discipline, } \\
\text { professional attitude, transparency, comply with } \\
\text { the main duties and functions, are honest and fair } \\
\text { in providing services to SMEs players in Bandung } \\
\text { Regency }\end{array}$ \\
\hline $\begin{array}{l}\text { Leadership and managerial } \\
\text { capacity }\end{array}$ & $\begin{array}{l}\text { The policy implementer already has a } \\
\text { leadership capacity }\end{array}$ & $\begin{array}{l}\text { Policy implementers already have good } \\
\text { leadership and managerial capacities, but there } \\
\text { needs to be an increase in supervision and } \\
\text { during implementation. }\end{array}$ \\
\hline Effectiveness & $\begin{array}{l}\text { The suitability of the implementer in the } \\
\text { implementation process with the policy } \\
\text { rules }\end{array}$ & $\begin{array}{l}\text { In the implementation process, the Official } \\
\text { Technical Team, Verification Team, and } \\
\text { Implementing Banks carry out their duties and } \\
\text { functions by policy regulations so that } \\
\text { implementation runs effectively }\end{array}$ \\
\hline Efficiency & $\begin{array}{l}\text { Use of the resources owned according to } \\
\text { the rules to achieve policy objectives }\end{array}$ & $\begin{array}{l}\text { Utilization of human resources, funds, and } \\
\text { facilities are used according to policy regulations, } \\
\text { but there is an increase in the number of } \\
\text { infrastructure such as a limited number of } \\
\text { transportation }\end{array}$ \\
\hline Economical & $\begin{array}{l}\text { The use of limited funds can achieve } \\
\text { policy objectives }\end{array}$ & $\begin{array}{l}\text { In the implementation process, the Dinas } \\
\text { Technical Team, Verification Team, and } \\
\text { Implementing Banks use limited funds but can } \\
\text { achieve policy objectives even though they are } \\
\text { less than optimal }\end{array}$ \\
\hline Responsive & $\begin{array}{l}\text { Implementing actors have sensitivity in } \\
\text { serving the community }\end{array}$ & $\begin{array}{l}\text { The Service Technical Team, Verification Team, } \\
\text { and implementing Bank in the implementation } \\
\text { process have sensitivity in serving SMEs }\end{array}$ \\
\hline Responsibility & $\begin{array}{l}\text { Implementing actors are responsible for } \\
\text { their duties }\end{array}$ & $\begin{array}{l}\text { The Service Technical Team, Verification Team, } \\
\text { and implementing Bank in the implementation } \\
\text { process are responsible for their duties but need } \\
\text { to increase capacity in providing SMEs services }\end{array}$ \\
\hline $\begin{array}{l}\text { The influence of the external } \\
\text { environment }\end{array}$ & $\begin{array}{l}\text { The social, economic, and political } \\
\text { environment }\end{array}$ & $\begin{array}{l}\text { There is the influence that is difficult to control by } \\
\text { the Technical Service Team, Verification Team, } \\
\text { and implementing Bank during the process of } \\
\text { implementing economic instability and changing } \\
\text { local officials so that adjustments are needed }\end{array}$ \\
\hline
\end{tabular}


The results of the analysis of the achievement of the implementation of the Equity Participation policy through the Empowerment Program for SMEs in Bandung Regency can be seen from Table 1.

\section{CONCLUSION}

Bandung Regency Regional Regulation Policy Number 7 of 2013 concerning Capital Participation in Non-Banking Microfinance Institutions (Cooperatives and Non-Cooperatives) Through banking has the main objective, namely to encourage real roles, SMEs so that they are more able to play a role as a forum for activities people's economy so that people's welfare increases.

The use of local revenue as SMEs loan funds has been formulated as a joint policy by the Bandung Regency Government and the Regional Representative Council of Bandung Regency. The results of this regional income loan are very useful for the community, especially members of the Bandung Regency SMEs who get loans to develop their businesses.

The limited amount of funds, human resources, facilities, and infrastructure during the implementation process of the capital participation policy has hampered services for SMEs and decreased community services.

The requirements needed to obtain capital from the Bandung Regency government for SMEs are easier and the process is faster and the interest is very low when compared to borrowing from other financial institutions. However, some business actors still find it difficult to fulfill several requirements such as the existence of a guarantee, having to be registered in a business group, an identity card that has expired, and making business proposals, and the business must be registered with the industry and trade office or have a registration number corporate taxpayers.

Regulations governing the empowerment of SMEs of Bandung Regency through capital participation require changes by the conditions for the existence of SMEs in Bandung Regency itself. Because during the period of implementation of Bandung Regency Regional Regulation Number 7 of 2013 concerning Equity Participation, it was enforced mainly concerning articles regulating capital participation, this was less than optimal. So it is necessary to make changes to the content so that implementation can be carried out well and on target.

Coordination and communication of each actor in the implementation of the capital participation policy has been coordinated and communicated well because the actors know that they are interdependent and cooperate. This can be seen by often holding meetings and meetings to discuss the implementation of the capital participation policy. As well as the authority to carry out the tasks assigned to each actor, the implementation of the capital investment policy has also been going well.

\section{REFERENCES}

1. Atkinson, G., Dietz, S., \& Neumayer, E. (2007). Handbook of sustainable development. In Handbook of Sustainable Development.

2. Bardach, E. (2009). Policy Dynamics. In The Oxford Handbook of Public Policy.

3. Bardach, E. (2017). Networks, Hierarchies, and Hybrids. International Public Management Journal.

4. BPS Provinsi Jawa Barat. (2018). Provinsi Jawa Barat Dalam Angka 2018. In BPS Provinsi Jawa Barat.

5. Budi, W. (2014). Kebijakan Publik (Teori, Proses, dan Studi Kasus). In Caps.

6. Carsrud, A., \& Cucculelli, M. (2014). Family firms, entrepreneurship, and economic development. Journal of Small Business Management.

7. Creswell, J. (2013). Qualitative, quantitative, and mixed methods approaches. In Research design.

8. Cucculelli, M., \& Bettinelli, C. (2016). Corporate governance in family firms, learning and 
reaction to recession: Evidence from Italy. Futures.

9. Cucculelli, M., \& Ermini, B. (2012). New product introduction and product tenure: What effects on firm growth? Research Policy.

10. Cucculelli, M., \& Peruzzi, V. (2017). Bank screening technologies and the founder effect: Evidence from European lending relationships. Finance Research Letters.

11. Cucculelli, M., \& Storai, D. (2018). Industrial districts, district effect and firm size: The Italian evidence. Cambridge Journal of Economics.

12. De Meza, D., Irlenbusch, B., \& Reyniers, D. (2008). Financial Capability: A Behavioural Economics Perspective. Financial Services Authority, July, 5-108.

13. Denzin, N. K., \& Lincoln, Y. S. (2000). Introduction: The discipline and practice of qualitative research. In Handbook of qualitative research (2nd edition).

14. Doern, G. B., \& Pal, L. A. (1988). Public Policy Analysis: An Introduction. Canadian Public Policy / Analyse de Politiques.

15. Dunn, W. N. (2003). Pengantar Analisis Kebijakan Publik. In Gadjah Mada University Press.

16. Dunn, W. N., \& Dunn, W. N. (2018). The Process of Policy Analysis. In Public Policy Analysis.

17. Dye, T. (2014). Top Down Policymaking. In Top Down Policymaking.

18. Dye, T. R. (2017). Understanding Public Policy. In Understanding Public Policy.

19. Edward III, G. C. (1984). Public Policy Implementing. In Literary and Linguistic Computing.

20. Fonseka, M. M., Tian, G. L., \& Li, L. C. (2014). Impact of financial capability on firms' competitiveness and sustainability: Evidence from highly regulated Chinese market. Chinese Management Studies.

21. Grindle, M. S. (2017). Politics and policy implementation in the third world. In Politics and Policy Implementation in the Third World.

22. Hean, S., Worswick, L., Fenge, L. A., Wilkinson, C., \& Fearnley, S. (2013). Keeping informed during times of economic downturn: The trusted amateur as a preferred source of financial information. Public Money and Management, 33(1), 23-30.

23. Huston, S. J. (2010). Measuring Financial Literacy. Journal of Consumer Affairs.

24. Johnson, E., \& Sherraden, M. S. (2007). From financial literacy to financial capability among youth. Journal of Sociology and Social Welfare.

25. Kurniawan. (2014). Faktor yang mempengaruhi akses keuangan pinjaman usaha mikro kecil dan memengah (UMKM) di Kabupaten Brebes. Jounal \& Proceding FEB Universitas Soedirman.

26. Kurniawan, F. D., \& Fauziah, L. (2014). Pemberdayaan Usaha Mikro Kecil Dan Menengah (Umkm) Dalam Penanggulangan Kemiskinan. JKMP (Jurnal Kebijakan Dan Manajemen Publik).

27. Lusardi, A., Mitchell, O. S., \& Curto, V. (2010). Financial literacy among the young. Journal of Consumer Affairs.

28. Meier, K. J., Ripley, R. B., \& Franklin, G. A. (1987). Policy ImplementationPolicy Implementation and Bureaucracy. Public Administration Review.

29. Miles, M. B., Huberman, M. a, \& Saldana, J. (2014). Drawing and Verying Conclusions. Qualitative Data Analysis: A Methods Sourcebook.

30. Nagel, E., \& Kaplan, A. (1965). The Conduct of Inquiry: Methodology for Behavioral Science. American Sociological Review.

31. Noctor, M., Stoney, S., \& Stradling, R. (1995). Financial literacy: a discussion of concepts and competences of financial literacy and opportunities for its introduction into young people's learning. National Foundation for Educational Research.

32. Omri, A., Frikha, M. A., \& Bouraoui, M. A. (2015). An empirical investigation of factors affecting small business success. Journal of Management Development.

33. Pal, L. A. (2005). Case study method and policy analysis. In Thinking Like a Policy Analyst: Policy Analysis as a Clinical Profession.

34. Pal, L. A., \& Ireland, D. (2009). The Public Sector Reform Movement: Mapping the Global Policy Network. International Journal of Public Administration. 
35. Rachbini, E. M. (2020). The importance of financial access for the poor. Journal of AsiaPacific Studies.

36. Solichin, A. W. (2017). Analisis Kebijakan Dari Formulasi ke Penyusunan Model-Model Implementasi Kebijakan Publik. In Bumi Akasara, Jakarta.

37. Suharto, E. (2006). Analisis kebijakan publik: panduan praktis mengkaji masalah dan kebijakan sosial. In Alfabeta.

38. Taylor, M. (2011). Measuring Financial Capability and its Determinants Using Survey Data. Social Indicators Research, 102(2), 297-314.

39. Taylor, S. M., \& Wagland, S. (2013). The Solution to the Financial Literacy Problem: What is the Answer? Australasian Accounting, Business and Finance Journal.

40. Uchida, H., \& Udell, G. (2012). Banking in Japan. In The Oxford Handbook of Banking.

41. Uchida, H., Udell, G. F., \& Watanabe, W. (2008). Bank size and lending relationships in Japan. Journal of the Japanese and International Economies.

42. Uchida, H., Udell, G. F., \& Yamori, N. (2008). How do Japanese banks discipline smalland medium-sized borrowers? An investigation of the deployment of lending technologies. In International Finance Review.

43. Uchida, H., Udell, G. F., \& Yamori, N. (2012). Loan officers and relationship lending to SMEs. Journal of Financial Intermediation.

44. Van Meter, D. S., \& Van Horn, C. E. (1975). The Policy Implementation Process: A Conceptual Framework. Administration \& Society.

45. Winarno, B. (2012). Kebijakan Publik (Teori, Proses, danWinarno, B. (2012) "Kebijakan Publik (Teori, Proses, dan Studi Kasus)," in Caps. Studi Kasus). In Caps.

46. Wright, S. R., \& Jenkins, W. I. (1979). Policy Analysis: A Political and Organizational Perspective. Contemporary Sociology.

47. Wulansari, N., Wahyu, \& Kurniawan, Y. (2017). Akselerasi pertumbuhan ekonomi melalui sinergi UMKM dan Good Governance di Indonesia. Prosiding Seminar Nasional Dan Call For Paper Ekonomi Dan Bisnis.

48. Xie, X., Zeng, S., Peng, Y., \& Tam, C. (2013). What affects the innovation performance of small and medium-sized enterprises in China? Innovation, 15(3), 271-286. 